\title{
Water quality assessment of the Triassic aquifer, SE Tunisia, for drinking water supply
}

\author{
Meriem Ameur ${ }^{1, *}$, Fadoua Hamzaoui-Azaza ${ }^{1}$, and Moncef Gueddari ${ }^{1}$ \\ ${ }^{1}$ Research Unit of Geochemistry and Environmental Geology, Faculty of Sciences, University of \\ Tunis el Manar, 2092, Tunisia,
}

\begin{abstract}
The Triassic aquifer is located in southereastern Tunisia, in the Medenine region, and being part of Jeffara's multilayer aquifer system. The aquifer is currently overexploited with an exploitation rate of $163 \%$, which led to a generalized drop in the piezometric level in the order of 20 $\mathrm{cm} /$ year. This study applied conventional techniques such as hydrochemical compositions, multivariate statistical methods and Geographical Information Systems (GIS). To better identify the processes controlling the hydrogeochemical evolution of groundwater quality of Triassic aquifer and its suitability for drinking uses, 14 well water samples from the Triassic aquifer were analysed for physical character and chemical composition. In the groundwater, the respective order of cation and anion concentration was $\mathrm{Na}>\mathrm{Ca}>\mathrm{Mg}>\mathrm{K}$ and $\mathrm{SO}_{4}>\mathrm{Cl}>\mathrm{HCO}_{3}$. The chemical data of water samples from the study area presented by plotting on a Piper diagram reveals the predominance of two hydrochemical types: a Na-Ca-Mg-SO ${ }_{4}$ facies and a Na-Ca-Mg-Cl-SO ${ }_{4}$ facies. Analytical results demonstrate that the chemical composition of groundwater in Triassic aquifer is strongly influenced by residence time and flow path. Water quality deteriorates going from southwest to northeast across the region, coincident with the appearance a clay layer limiting the infiltration of rainwater. The majority of ions are above the maximum desirable limits recommended for drinking water by WHO guidelines and Tunisian Standards (NT.09.14). Based on the Water Quality Index (WQI), 36\% of water samples of the Triassic aquifer are classified as "poor water" and they cannot be used for drinking purposes without prior treatment.
\end{abstract}

\section{Introduction}

Tunisia is a country with semi-arid to arid climate over most of its territory. It is influenced by two very different climates, one Mediterranean to the north and the other Saharan to the south, which causes significant spatial-temporal variation of water resources [1]. The southern part of Tunisia is marked by a high degree of aridity, with a very deficient water balance, and lack of permanent surface-water reservoirs. Mean annual rainfall is 100 to $230 \mathrm{~mm}$ and annual evaporation is 1300 to $1600 \mathrm{~mm}$ [2]. In this context, the exploitation of deep aquifers having considerable reserves remains indispensable in order to meet the

\footnotetext{
*Corresponding author: meriem_ameur@yahoo.fr
} 
needs of the continuously growing population. A Triassic aquifer of southeastern Tunisia, which extends over $515 \mathrm{~km}^{2}$, is the major source for fresh water for human consumption and irrigation purposes in the Medenine Governorate. The surface hydrographical network in the study area is quite dense. The geology of the region is characterized by the presence of alternations of formations of continental origin and others of marine origin [3], and the stratigraphic series that outcrops in the study area ranges from the Upper Permian to the Quaternary [4]. The general groundwater flow of the aquifer is from southwest to northeast (Fig. 2), in the same direction of the Miocene and Jurassic aquifer unit [5]. The Triassic aquifer constitutes an important water source and is used for various purposes. Since 1980s, the piezometric level shows an average decline of $0.20 \mathrm{~m} /$ year under the effect of the current extraction (Fig. 2).

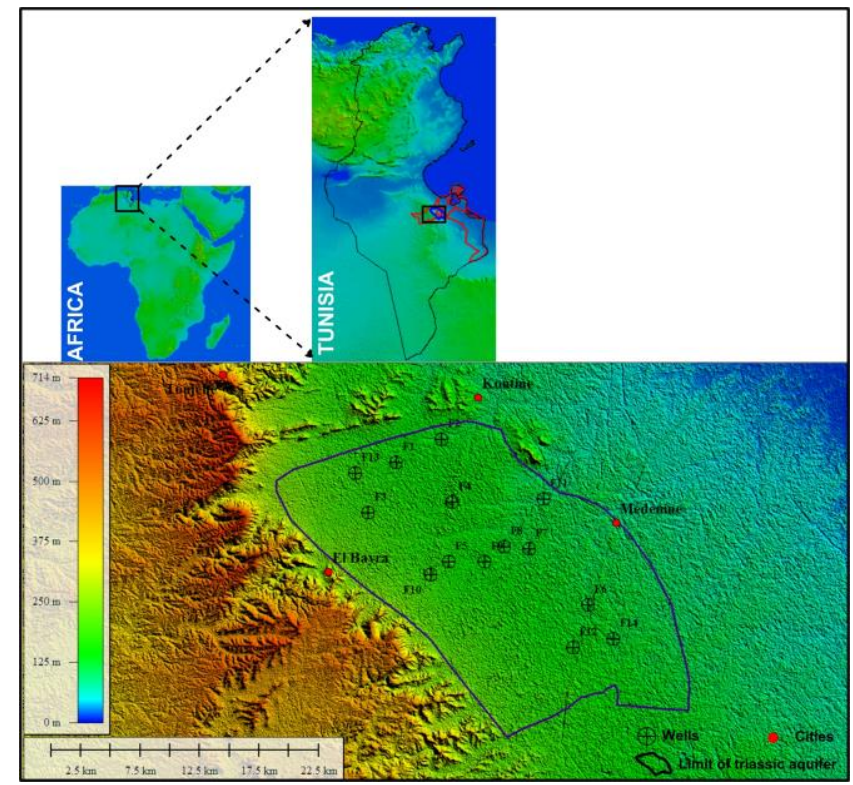

Fig. 1. Location map of the study area.

\section{Materials and methods}

\subsection{Sample collection, and analytical techniques}

In order to identify the chemical composition of the Triassic aquifer, 14 groundwater samples were collected from actively pumped wells after 10 minutes of pumping to guarantee the homogeneity of the samples. The water samples were analyzed for physicochemical parameters, such as temperature, $\mathrm{pH}$, salinity, $\mathrm{Na}^{+}, \mathrm{K}+, \mathrm{Ca}^{2+}, \mathrm{Mg}^{2+}, \mathrm{Cl}^{-}, \mathrm{F}^{-}$ , $\mathrm{HCO}_{3}{ }^{-}$, and $\mathrm{SO}_{4}{ }^{2-}$. The physical parameters $(\mathrm{pH}$, salinity and temperature) were measured in situ, and the major elements and $\mathrm{F}$ were measured in the laboratory. Samples were collected in sterilized polyethylene bottles, transported and stored in coolers at $4{ }^{\circ} \mathrm{C}$. In the laboratory, the samples were filtered with a $0.45 \mu \mathrm{m}$ diameter membrane. By adding $35 \%$ $\mathrm{HNO}_{3}$ until reaching $\mathrm{pH}<2$, the samples were well preserved [6]. The analyses were conducted in the laboratory of the drinking water treatment plant in Tunis according to a standard water analysis protocol. This laboratory has been certified by the French Council for Accreditation, Audit and Control COFRAC according to ISO 17025, the latest version 
of the international standards for laboratory competence. The interpretation of geochemical data was based on data plots and a spatial distribution map of hydrochemical facies.

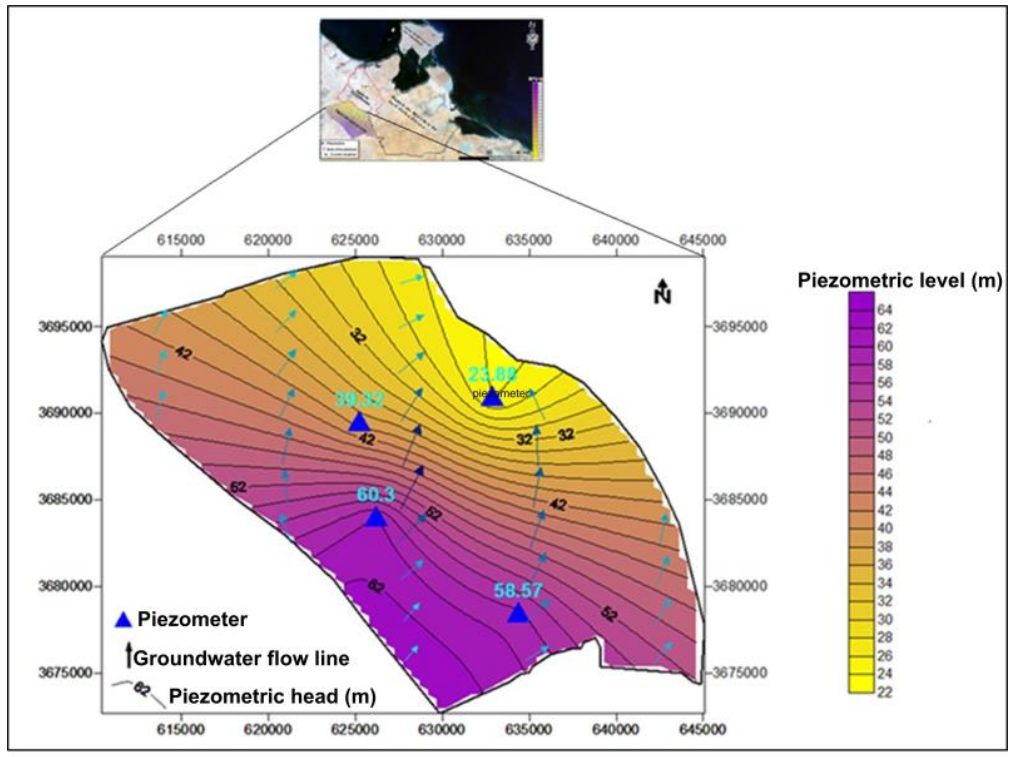

Fig. 2. Piezometric map of the Triassic aquifer.

\subsection{GIS analysis}

We used a Geographical Information System approach to visualizing the chemical variability groundwater within the Triassic aquifer in order to produce a set of digital and thematic maps. With the development of GIS, one is able to make spatial distributions of the Water Quality Index (WQI).

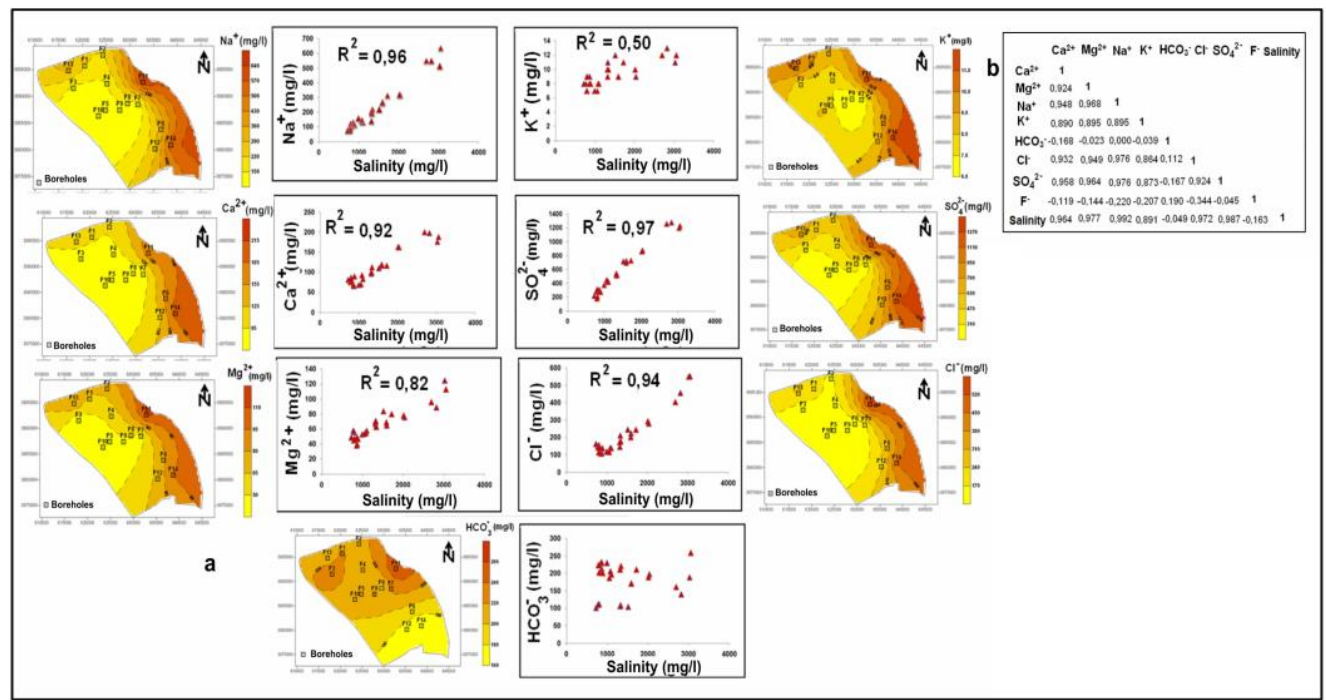

Fig. 3. (a); Concentrations (mg/L) of major ions as a function of salinity in Triassic aquifer with their spatial distribution maps; (b) Correlation matrix of chemical parameters of the Triassic aquifer [7]. 


\section{Results and discussion}

\subsection{Spatial analysis of groundwater chemistry and statistical analyses}

The results of spatio-temporal monitoring of the salinity and the major element contents of waters of the Triassic aquifer show that salinity, mainly controlled by $\mathrm{Na}^{+}, \mathrm{Ca}^{2+}, \mathrm{Cl}^{-}$and $\mathrm{SO}_{4}{ }^{2-}$ concentrations, increases from upstream to downstream (Fig. 3a). The upstream zone, captured at depths less than $200 \mathrm{~m}$, is under the influence of a major recharge from the wadis. In the downstream zone, the aquifer is under a thick series of clays and becomes captive, which explains the highest salinity recorded in the southern and eastern parts of the aquifer, so an increase in mineralization in the direction of flow of the aquifer. The concentrations of $\mathrm{Na}^{+}, \mathrm{Cl}^{-}, \mathrm{Ca}^{2+}$ and $\mathrm{SO}_{4}{ }^{2-}$ are very well correlated with salinity, with correlation coefficients of $0.96,0.94,0.92$ and 0.97 , respectively (Fig. 3b). The contents of $\mathrm{K}^{+}$and $\mathrm{Mg}^{2+}$ are also positively correlated with salinity, but with correlation coefficients of 0.5 and 0.82 , respectively. However, the concentration of $\mathrm{HCO}_{3}{ }^{-}$is very weakly correlated with the total salt content. This shows that the variation of salinity is not influenced by bicarbonate ions.

\subsection{Hydrogeochemical facies}

The representation of the concentration percentages of the major ions of Triassic aquifer in the Piper diagram shows the predominance of two hydrochemical types:

- A Na-Ca-Mg-SO facies for waters of the boreholes F1, F3, F4, F5, F7, F8, F9, F13 and F10 that are located in the upstream part of the aquifer corresponding with the recharge zone;

- A Na-Ca-Mg-Cl-SO 4 facies, which characterize the waters of drillings F2, F6, F11, F12 and $\mathrm{F} 14$, located in the discharge zone of the aquifer. A change in the hydrochemical facies from upstream to downstream is observed with a decrease of bicarbonate contents and an increase of sodium and chloride contents as well as an increase of the $\mathrm{SO}_{4} / \mathrm{Ca}$ ratio.

Table 1. Calculation of Water Quality Index for the Triassic aquifer of southeaster Tunisia.

\begin{tabular}{|c|c|c|}
\hline WQI values & Water quality & Water samples (\%) \\
\hline$<50$ & excellent & 0 \\
\hline $50-100$ & good quality water & 64 \\
\hline $100-200$ & poor quality water & 36 \\
\hline $200-300$ & very poor quality & 0 \\
\hline$>300$ & unfit for consumption & 0 \\
\hline
\end{tabular}

\subsection{Suitability of Triassic aquifer water for drinking purposes}

The Water Quality Index WQI) is an important and very effective parameter to evaluate the suitability of water for human consumption. The WQI can be calculated as follows:

$$
\begin{aligned}
& W i=w i / \sum n i=1 \quad w i \\
& q i=(\mathrm{Ci} / \mathrm{Si}) * 100 \\
& S I i=W i * q i \\
& W Q I=\sum S I i
\end{aligned}
$$


where 'wi' is the weight of each parameter, ' $n$ ' is the number of parameters, ' $\mathrm{Ci}$ ' is the concentration of an element ' $\mathrm{I}$ ' in each water sample in $\mathrm{mg} / \mathrm{L}$, and 'SI' is the Maximum Permissible Concentration set according to the standards of WHO. WQI values determined for the Triassic aquifer groundwater are listed in Table 1. The waters of the Triassic aquifer are qualified as good quality within a range of $50<\mathrm{WQI}<100$. For the Triassic aquifer of southeastern Tunisia, $64 \%$ of samples display a 'good quality' WQI and $36 \%$ 'poor quality' WQI between $100<\mathrm{WQI}<200[6]$.

\section{Conclusions}

The Triassic aquifer, located in southeastern Tunisia, is exploited to meet the growing needs of the population for domestic purposes. The calculation of the water quality index (WQI) has shown that $64 \%$ of the water aquifer is of good quality for human consumption, located mainly in the western part of the aquifer (F5, F8, F9, F10 ...), and $36 \%$ of the water is of poor quality, that concern the waters of the eastern and southern part of the aquifer (F11 and F14). GIS combined with other geochemical software provides a complete information in real-time about the quality of water resources, their use and their spatial distribution. These results are an effective decision-support tool for evaluating the water quality of the Triassic aquifer.

\section{References}

1. M. Ameur, et al., Env. Geochem. Health, 38, 1147-1167 (2015)

2. M. Ouessar, et al., Env. Monit. Assess, 99, 127-140. (2004)

3. S. Bouaziz, La déformation dans la plate forme du Sud Tunisien (Dahar et Jeffara): Approche multiscalaire et pluridisciplinaire. Thèse Doc de spécialité. E.N.I.Sfax, 180 (1986)

4. G. Busson, G. Le, Mésozö̈que Saharien. lère partie: L'extrême Sud Tunisien. Série géologique, Ed Centre Nat Paris, 8, 194 (1967)

5. F. Hamzaoui, et al., J. Appl. Sci. Res., 5, 1941-1951 (1967)

6. M. Ameur, Géochimie des eaux de la nappe des Grés du Trias dans le Sud-est de la Tunisie. Rapport de Mastère, Université Tunis el Manar FST, 155 (2011)

7. J.H. Ward, J Am Stat Assoc, 69, 236-244 (1963) 